Любий Є.В., Бєлецька О.М.

Харківський національний автомобільно-дорожній університет, Украйна

\title{
ЕКСПЕРИМЕНТАЛЬНІ ДОСЛІДЖЕННЯ ЗАТРИМОК ТРАНСПОРТНИХ ЗАСОБІВ ПРИ ВИЇЗДІ 3 ПРИЛЕГЛИХ ТЕРИТОРІЙ
}

\begin{abstract}
Представлена робота присвячена вивченню проблеми визначення затримок транспортних засобів при виїзді з прилеглих територій на міські автомагістралі. На даний час вже існує велика кількість різних підходів щодо визначення транспортних затримок на нерегульованих перехрестях, але вони не в повній мірі враховують особливості руху автомобілів на виїздах з прилеглих територій.

На основі результатів натурних спостережень за рухом транспортних засобів при виїзді з прилеглих територій в статті проведено оцінювання результатів визначення затримок за запропонованим підходом, в який закладено принципи системи масового обслуговування, що дозволяє враховувати пріоритетність руху автомобілів на конкуруючих напрямках. Встановлено, що відхилення фактичних транспортних затримок $\mathrm{i}$ затримок отриманих за запропонованим підходом для обох маневрів, поворот праворуч (злиття) $\mathrm{i}$ ліворуч (пересічення) не перевищує 10 \%, що свідчить про можливість його використання на таких об'єктах як виїзди з прилеглих територій. На основі отриманих емпіричних даних встановлено, що розподіл фактичних затримок транспортних засобів при виїзді 3 прилеглих територій для всіх досліджуваних випадків відповідає логнормальному закону з достатньо високою імовірністю.

Для зменшення відхилень модельних і фактичних значень транспортних затримок при виїзді 3 прилеглих територій необхідно в моделі врахувати стохастичні характеристики параметру процесу здійснення відповідних маневрів. Таким параметром є граничний часовий інтервал між автомобілями в потоці на головному напрямку, за якого будь-який автомобіль, що очікує на здійснення маневру при виїзді з прилеглих територій, може виконати поворот праворуч або ліворуч, який можна визначити за рахунок проведення статистичної обробки результатів натурних спостережень.

Ключові слова: транспортний потік, затримка, граничний інтервал, виїзд 3 прилеглої території, натурні спостереження.
\end{abstract}

\section{ВСТУП}

Вплив транспорту на навколишнє середовище багато в чому визначається випадками простою та затримок. Затримка - широко використовувана міра обслуговування для перехресть, а також фундаментальний параметр в економічному аналізі інвестицій в автомобільні дороги [1]. Затримки вказують на зайвий час, що споживається транспортним засобом, у порівнянні 3 контрольним значенням.

У більшості випадків затримки транспортних засобів є локальною та окремою (часною) проблемою, яка може спостерігатися та досліджуватися не тільки в аспекті планування розвитку всієї міської території, але також й на невеликих ділянках місцевості. Тому для зменшення транспортних затримок на вулично-дорожній мережі необхідно не тільки визначати раціональний світлофорний цикл на регульованих перехрестях, а й приділяти особливу увагу їх зниженню на нерегульованих перехрестях і на інших «вузьких» місцях міської транспортної системи, якими є виїзди $з$ прилеглих територій. На виїздах $з$ прилеглих територій дуже часто виникають конфліктні моменти, в наслідок чого, створюються аварійні ситуації з реальним збитком. Таким чином проблема, що розглядається, носить не тільки технічний, але й соціально-економічний характер.

\section{АНАЛІЗ ЛІТЕРАТУРНИХ ДАНИХ ТА ПОСТАНОВКА ПРОБЛЕМИ}

Транспортна система сучасного великого міста складається зі значної кількості конфліктних місць, серед яких переважають нерегульовані перехрестя та виїзди з прилеглих територій. Такі об'єкти є місцями концентрації дорожньо-транспортних пригод та утворення заторів, які призводять до зростання транспортних затримок, точних методів оцінювання яких на даний час немає. Також слід відзначити, що останнім часом при розрахунку швидкості руху в сфері транспортного моделювання акценти переносяться 3 ділянок вулично-дорожньої мережі на місця перетину потоків учасників дорожнього руху, а методики, що дозволяють точно оцінити тимчасові затримки транспорту, розроблені, в основному, для регульованих перехресть [2].

У відповідності до Правил дорожнього руху України [3] «перехрестя - місце перехрещення, прилягання або розгалуження доріг на одному рівні, межею якого є уявні лінії між початком заокруглень країв проїзної частини кожної з доріг. Не вважається перехрестям місце прилягання до дороги виїзду з прилеглої території». В свою чергу, прилеглою є територія, що прилягає до краю проїзної частини та не призначена для наскрізного проїзду, а лише для в”їзду до дворів, на стоянки, 
автозаправні станції, будівельні майданчики тощо або виїзду з них. Отже, відповідно до наведених вище понять, основна відмінність перехрестя та прилеглої території полягає в об'єктах інфраструктури, до яких веде проїжджа частина, що пересікається, а також у технічних засобах регулювання дорожнього руху, які їх позначають. Велика кількість таких «вузьких» місць на вулично-дорожній мережі великого міста створює значні незручності як для транспортних засобів, що рухаються головним напрямком, так й для тих, що виїжджають 3 прилеглих територій. Особливо гострим це питання постає при необхідності виконання маневру лівого повороту при виїзді 3 прилеглої території на магістральні вулиці та дороги [4].

В існуючій нормативній та науковій літературі відсутні приклади визначення затримок транспортних засобів при виїзді $з$ прилеглих територій, що пов'язано з низькою зацікавленістю спеціалістів і науковців щодо питань підвищення ефективності дорожнього руху на такого роду об'єктах. Але слід зауважити, що за останні часи суттєво змінилися структура забудови великих українських міст, окрім житлової забудови активно з'являються великі торгові центри, супермаркети, гіпермаркети тощо, для ефективного транспортного обслуговування яких облаштовуються відповідні в ’ізди та виїзди. До цього слід також додати значний стрибок рівня автомобілізації, що набув місця за останні два-три роки. Ці процеси призвели до появи великої кількості конфліктних ситуацій при в’їзді та виїзді на прилеглу територію та необхідність вирішення проблеми облаштування таких місць відповідними технічними засобами регулювання дорожнього руху та визначення транспортних затримок на них. Найбільш схожим об'єктом на виїзди/в 'їзди на прилеглу територію є нерегульовані перехрестя, тому далі розглянемо існуючі підходи щодо визначення затримок транспортних засобів на таких перехрестях.

Умовно підходи щодо визначення затримок транспортних засобів можна поділити на три групи: проведення натурних досліджень за трафіком; різні аналітичні моделі, що описують затримки 3 урахуванням детермінованих і стохастичних властивостей транспортного потоку та підходи засновані на використанні мікромоделювання та регресійних моделей. Основним недоліком першої групи підходів $є$ значна трудомісткість виконання обстеження та обробки результатів. Перевагою, в свою чергу, є висока точність отриманих результатів. Слід зауважити, що зменшити трудомісткість обробки результатів натурних спостережень за затримками транспортних засобів можливо за рахунок використання автоматизованих систем розпізнавання та підрахунку трафіка.

Інша група підходів щодо визначення затримок на нерегульованих перехрестях представлена великою кількістю моделей. Зарубіжна теорія транспортного регулювання концентрується на оцінках затримок і довжини черг. Транспортні затримки та довжина черги транспортних засобів $\epsilon$ основними показниками, що вводять поняття рівня обслуговування (LOS) і які використовуються при оцінці достатності довжини смуги руху перед перехрестям [5].

Одним $з$ перших підходів щодо визначення затримок на нерегульованому перехресті є підхід Tanner [6], основою якого є наступні положення: транспортні засоби прибувають до перехрестя випадковим чином; головний потік руху створює процес чергування, що оновлюється 3 часом, витраченим на перетин перехрестя групою автомобілів, при цьому інтервали часу між групами автомобілів розподіляються за експоненціальним законом; транспортні засоби другорядного напрямку перетинають головну дорогу в рівні проміжки часу протягом представленого інтервалу, який обмежується часом прибуття наступної групи транспортних засобів.

В своїй роботі [7] Troutbeck запропонував враховувати в моделі визначення затримок транспортних засобів на нерегульованих перехрестях наступні параметри: середню затримку при незначному другорядному потоці (також відому як Adams delay); ступінь насичення другорядного потоку; показник, кількісно визначає ефект організації черги другорядного потоку.

Для перехресть, що мають пріоритет руху, Heidemann у роботі [8] представив формулу для розрахунку затримок транспортного потоку на другорядній дорозі як функцію від ступеня насичення. В свою чергу, автори [9] розділили загальну затримку на перехрестях 3 двостороннім контролем зупинки на затримку в черзі та затримку на обслуговування. У цьому випадку затримка в черзі визначається часом від моменту прибуття транспортного засобу в кінець черги до моменту його підходу до стоп-лінії, а затримка на обслуговування представлена як час між прибуттям транспортного засобу до стоп-лінії та відправленням з неї.

Horowitz в дослідженні [10] удосконалив модель очікування в черзі для перехресть 3 повністю контрольованою зупинкою, відбивши в ній емпіричну інформацію про поведінку водіїв, а авторами [11] розроблено ймовірнісну модель затримок, яка відображає поведінку водіїв при прийнятті рішення на здійснення маневру, що може бути використано для описання повороту праворуч на Т- 
подібному перехресті. В роботі [12] Кауsі та Alam досліджували вплив поведінки водія (нетерпіння, агресивність, досвід) на розмір затримки транспортних засобів.

У дослідженні [13] проведено порівняння трьох основних на той час моделей затримки на нерегульованих перехрестях: модель НСM 94, модель Akcelik-Troutbeck та модель SIDRA 5. У роботі показані різні відмінності в результатах розрахунків і запропоновані вдосконалені варіанти цих моделей на основі результатів математичного моделювання.

Загальна затримка на нерегульованому перехресті з відносним пріоритетом відповідно до [14] має чотири складові: затримку на уповільнення (гальмування); затримку в черзі; затримку на очікування можливості здійснення повороту (час очікування розриву в головному потоці); затримку на прискорення (розгін).

В своєму дослідженні [15] авторами Al-Omari i Benehokal розроблено моделі для оцінювання затримки в черзі та затримки обслуговування на перехрестях 3 двостороннім контролем зупинки. Затримка обслуговування оцінюється як функція від обсягів конфліктуючих потоків, а середнє значення затримки обслуговування та її дисперсія використовуються в якості вхідних параметрів для оцінювання затримки.

На основі результатів моделювання трафіку в роботі [16] отримано узагальнену форму моделі затримки, яка дає більш точні результати, ніж проста експоненціальна форма загальної затримки транспортного потоку на перехрестях з повністю контрольованою зупинкою.

В своїй роботі автори [17] розробили модель для оцінки загальної затримки на нерегульованих перехрестях 3 використанням положень теорії черг, а автор [18] намагався перевірити методи розрахунку затримок, в основу яких закладена теорія масового обслуговування. Для отримання чисельно точних результатів авторами розроблена методика з використанням Марковських ланцюгів. Дані стохастичного моделювання та дані, отримані емпіричним шляхом, використовувалися для оцінки точності отриманих апроксимуючих моделей.

Transportation Research Board y [19] представлено процедуру оцінки транспортних затримок на нерегульованих перехрестях, у відповідності до якої затримки визначаються окремо для кожного другорядного напряму та лівоповоротних потоків головного напрямку. Згідно цього дослідження, затримка визначається як загальний час, що минув з моменту зупинки транспортного засобу в кінці черги до моменту його від'їду від лінії зупинки. Аналогічний підхід використовується й в Malaysian Highway Capacity Manual.

Автором дослідження [20] запропоновано новий підхід до визначення затримок на нерегульованих перехрестях, який дає можливість оцінки середньої затримки в залежності від варіативності попиту на трафік. Перевагою даного підходу є можливість отримання достатньо точних результатів для тривалого періоду, наприклад, доби.

Окрему групу становлять підходи щодо визначення затримок на нерегульованих перехрестях, засновані на використанні засобів мікромоделювання та регресійних залежностей. Особливої уваги заслуговує робота Caliendo [21], представлені в ній моделі часу затримок, часу простою i максимальної черги розроблені з використанням AIMSUN і можуть бути використані для прийняття рішень проектувальниками транспортної інфраструктури та операторами дорожнього руху. 3 останніх досліджень також можна виділити роботу [22], в якій проведено моделювання транспортних затримок на нерегульованих перехрестях з використанням штучної нейронної мережі на прикладі Малайзії. Результати цього дослідження показали, що нейронна мережа здатна більш точно прогнозувати затримку на нерегульованих перехрестях ніж підходи представлені в Malaysian Highway Capacity Manual i Highway Capacity Manual (2010). Точність розроблених моделей оцінена на підставі результатів натурних спостережень на трьох перехрестях з різною конфігурацією.

Результати проведеного аналізу існуючих підходів щодо визначення затримок свідчать про те, що більшість розглянутих підходів застосовуються на прикладі нерегульованих перехресть двох типів: $з$ двостороннім контролем зупинки та $з$ повністю контрольованою зупинкою. Це говорить про необхідність розробки моделей для визначення затримок на нерегульованих перехрестях, $з$ відмінною від світової практики організацією дорожнього руху, наприклад, на нерегульованих перехрестях рівнозначних доріг, що часто зустрічаються на території українських міст, а також для таких об'єктів як виїзди 3 прилеглих територій. Авторами даного дослідження розроблено аналітичні моделі, використання яких можливо на різних типах нерегульованих перехресть [23, 24]. В основу запропонованих моделей закладено принципи найпростішого потоку, що дозволяє врахувати пріоритетність проїзду автомобілів в конфліктуючих напрямках, але їх використання на прикладі 
виїздів 3 прилеглих територій потребує додаткової апробації, що є однією 3 задач даного дослідження.

\section{ЦІЛЬ ТА ЗАДАЧІ ДОСЛІДЖЕННЯ}

Метою даного дослідження є визначення затримок транспортних засобів при виїзді з прилеглих територій. Основними задачами роботи $є$ : проведення натурних спостережень за рухом транспортних засобів при виїзді з прилеглих територій; встановлення закону розподілу фактичних затримок транспортних засобів при виїзді з прилеглих територій; розрахунок затримки транспортних засобів при виїзді з прилеглих територій за результатами спостережень та з використанням запропонованого підходу; оцінка отриманих результатів розрахунку затримки транспортних засобів при виїзді 3 прилеглих територій.

\section{РЕЗУЛЬТАТИ ДОСЛІДЖЕНЬ}

Об’єктом дослідження даної роботи є процес формування затримок транспортних засобів при виїзді з прилеглих територій. Основною характеристикою цього процесу є фактична транспортна затримка, яка, в свою чергу, є випадковою величиною, оскільки вона являється результатом натурних спостережень.

Для отримання вихідної інформації, що необхідна для встановлення значень транспортних затримок було проведено відеоспостереження за рухом транспортних засобів на виїзді 3 прилеглих прибудинкових територій по вул. Академіка Заболотного між вулицями Академіка Сахарова та Семена Палія в місті Одесі. Відеоспостереження було організовано таким чином, щоб була можливість зафіксувати рух транспортних засобів у всіх напрямках (рис. 1). Обстеження проводилося протягом тижня (робочі дні, понеділок-п’ятниця), тривалість відеофіксації одна година в проміжки часу 3 найбільшим навантаженням на вулично-дорожню мережу: ранковий період «пік» - 7:30-8:30 (квітень 2021 року) та вечірній період «пік» - 18:00-19:00 (червень 2020 року).
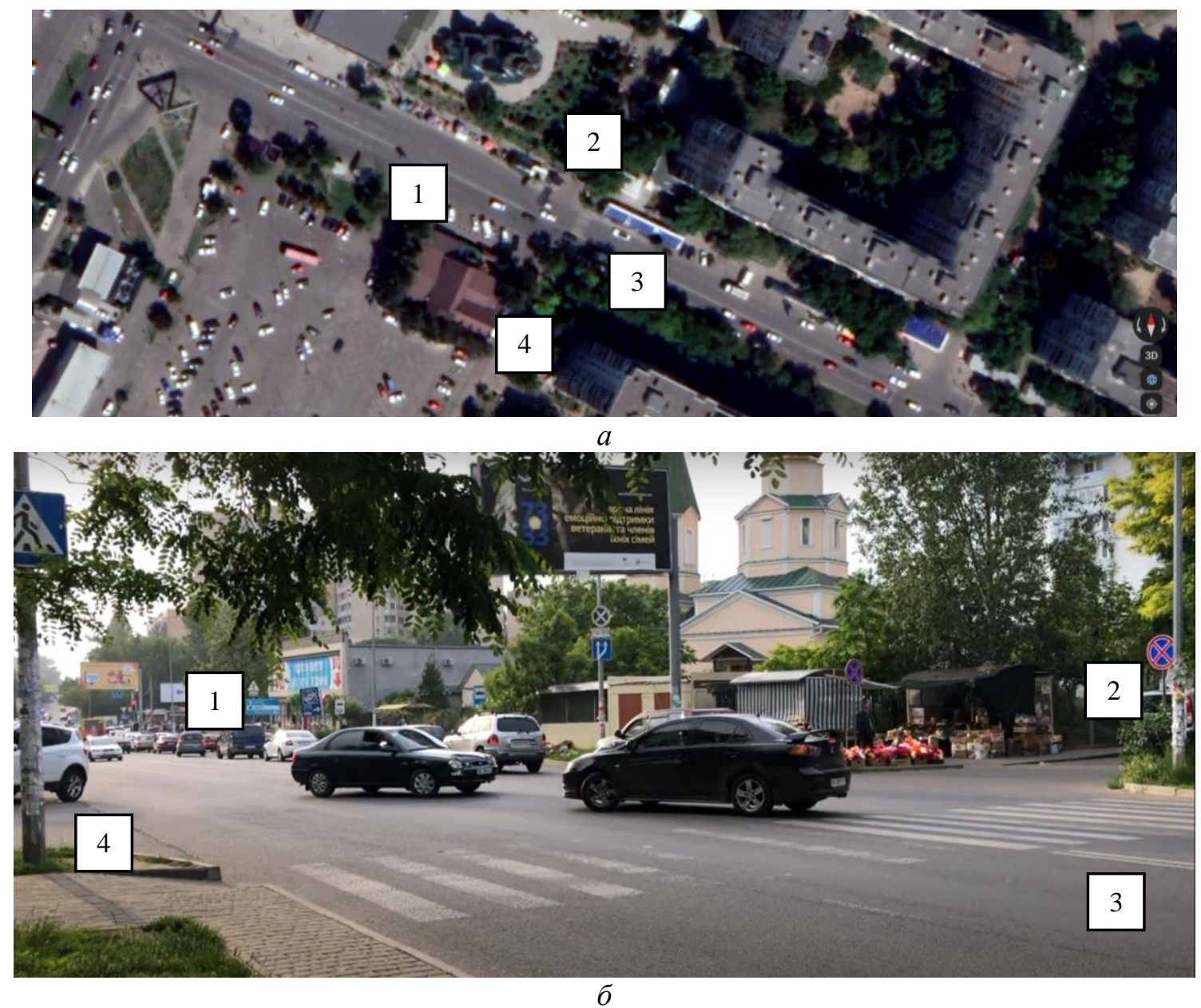

Рисунок 1 - Місце проведення натурних спостережень

( $a$ - план-схема об'єкту (Google Maps); $\sigma$ - приклад відеофіксації руху транспортних засобів)

В результаті обробки отриманої інформації сформовано масив даних для розрахунку затримок транспортних засобів на виїзді з прилеглої території за методикою наведеною в [24] (інтенсивності 
руху автомобілів головним (основним) і другорядним напрямком, часові інтервали на здійснення маневрів поворотів на виїздах $з$ прилеглих територій, часовий інтервал між транспортними засобами на головній дорозі), а також на основі якого встановлюються фактичні значення середньої транспортної затримки автомобілів при виїзді з прилеглих територій. Також отримані в результаті натурних спостережень дані є вихідною інформацією для визначення виду та параметрів закону розподілу фактичних транспортних затримок при виїзді транспортних засобів з прилеглих територій. Результати визначення закону розподілу фактичних затримок наведені на рисунках 2, 3 .
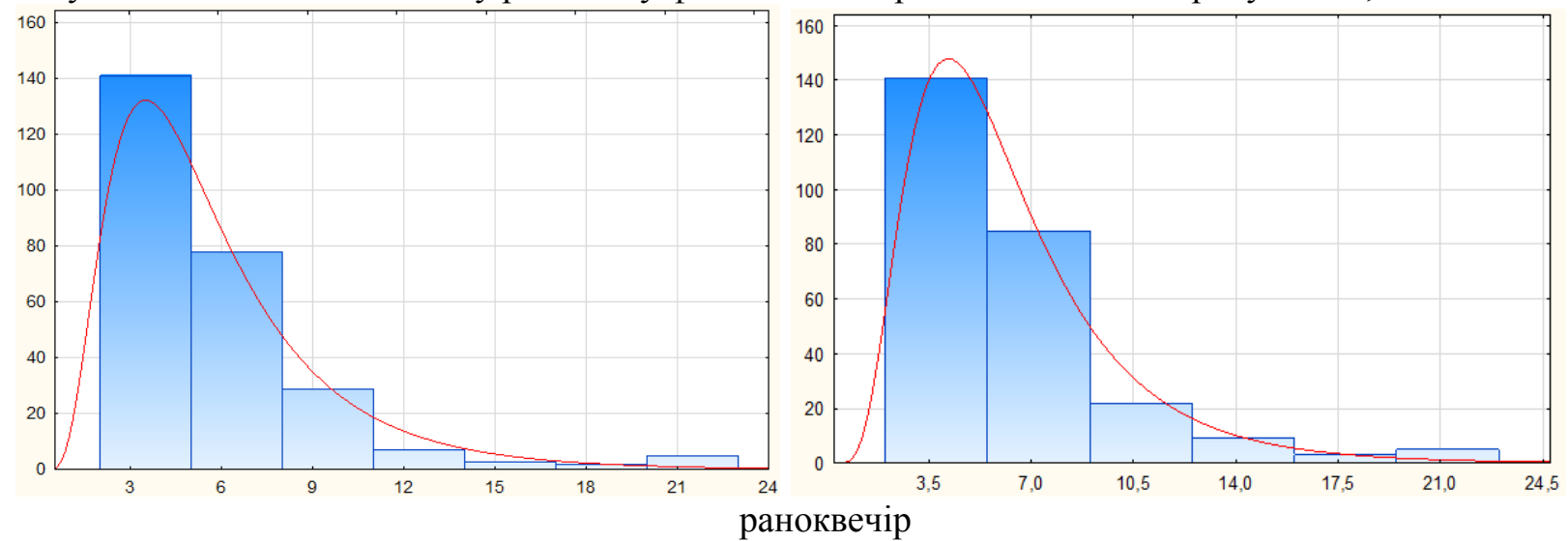

Рисунок 2 - Розподіл фактичних транспортних затримок при здійсненні маневру повороту праворуч при виїзді з прилеглих прибудинкових територій по вул. Академіка Заболотного між

вулицями Академіка Сахарова та Семена Палія (вісь $x$ - значення фактичних затримок, с; вісь $y$ - частота потрапляння значень затримок у відповідний інтервал)

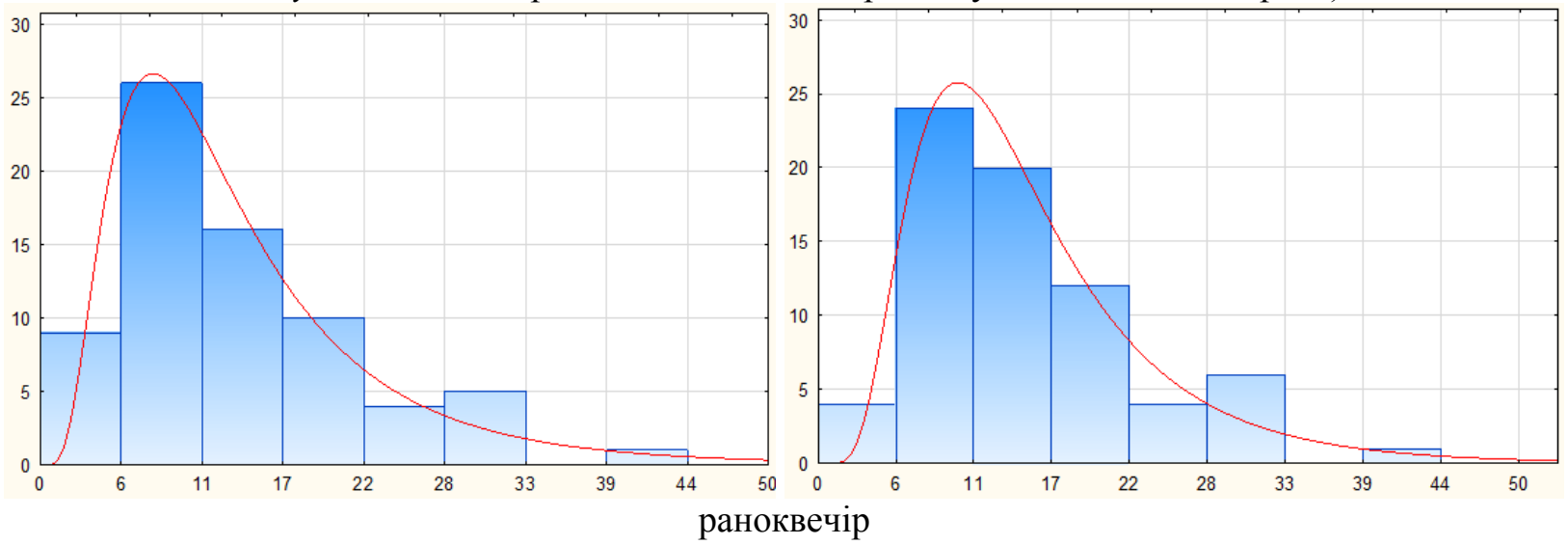

Рисунок 3 - Розподіл фактичних транспортних затримок при здійсненні маневру повороту ліворуч при виїзді з прилеглих прибудинкових територій по вул. Академіка Заболотного між вулицями

Академіка Сахарова та Семена Палія (вісь $x$ - значення фактичних затримок, с; вісь $y$ - частота потрапляння значень затримок у відповідний інтервал)

Встановлено, що розподіл фактичних затримок транспортних засобів при виїзді з прилеглих територій для всіх досліджуваних випадків відповідає логнормальному закону з достатньо високою імовірністю (таблиця 1).

Наведені в таблиці 1 емпіричні значення середньої затримки транспортних засобів, що виїжджають 3 прилеглої території на автомагістраль (вул. Академіка Заболотного) є основою для перевірки точності моделювання транспортної затримки за розробленою методикою [24]. Інформація про оцінювання точності результатів моделювання затримок транспортних засобів при виїзді 3 прилеглих територій по запропонованій методиці [24] наведені в таблиці 2.

Таблиця 1 - Параметри логнормального закону розподілу фактичних транспортних затримок при виїзді з прилеглих прибудинкових територій

\begin{tabular}{|c|c|c|c|c|}
\hline \multirow{3}{*}{ Параметр } & \multicolumn{4}{|c|}{ Маневр транспортного засобу при виїзді з прилеглої території за періодами } \\
\cline { 2 - 6 } & $\begin{array}{c}\text { Поворот праворуч } \\
\text { (напрями 2-1, 4-3) }\end{array}$ & $\begin{array}{c}\text { Поворот праворуч } \\
\text { (напрями 2-1, 4-3) }\end{array}$ & $\begin{array}{c}\text { Поворот ліворуч } \\
\text { (напрями 2-3, 4-1) }\end{array}$ & $\begin{array}{c}\text { Поворот ліворуч } \\
\text { (напрями 2-3, 4-1) }\end{array}$ \\
\hline
\end{tabular}


() Любий Є.В., Бєлецька О.М. 2021

\begin{tabular}{|l|c|c|c|c|}
\hline & $\begin{array}{c}\text { ранковий } \\
\text { «піковий» період }\end{array}$ & $\begin{array}{c}\text { вечірній } \\
\text { «піковий» період }\end{array}$ & $\begin{array}{c}\text { ранковий } \\
\text { «піковий» період }\end{array}$ & $\begin{array}{c}\text { вечірній } \\
\text { «піковий» період }\end{array}$ \\
\hline $\begin{array}{l}\text { Середнє значення, } \\
\text { с }\end{array}$ & 5,83 & 6,33 & 13,65 & 15,11 \\
\hline $\begin{array}{l}\text { Стандартне } \\
\text { відхилення, с }\end{array}$ & 13,98 & 14,70 & 61,53 & 62,99 \\
\hline $\begin{array}{l}\text { Значення критерія } \\
\text { Колмогорова- } \\
\text { Смирнова }\end{array}$ & 0,02488 & 0,02913 & 0,03031 & 0,02723 \\
\hline $\begin{array}{l}\text { Значення критерія } \\
\text { Пірсона }\end{array}$ & 2,66007 & 4,0097 & 0,21615 & 1,01382 \\
\hline $\begin{array}{l}\text { Імовірність за } \\
\text { критерієм Пірсона }\end{array}$ & 0,26447 & 0,135 & 0,898 & 0,602 \\
\hline
\end{tabular}

Таблиця 2 - Результати оцінювання точності розрахунку затримок транспортних засобів при виїзді 3 прилеглих прибудинкових територій по вул. Академіка Заболотного між вулицями Академіка Сахарова та Семена Палія

\begin{tabular}{|c|c|c|c|c|c|c|c|c|}
\hline \multirow[t]{2}{*}{ День тижня } & \multicolumn{2}{|c|}{$\begin{array}{c}\text { Затримка } \\
\text { транспортних засобів } \\
\text { при здійсненні } \\
\text { повороту праворуч } \\
\text { (напрями 2-1 та 4-3 } \\
\text { рисунку 1), с } \\
\end{array}$} & \multicolumn{2}{|c|}{$\begin{array}{c}\text { Фактичні } \\
\text { значення } \\
\text { затримок, с }\end{array}$} & \multicolumn{2}{|c|}{$\begin{array}{c}\text { Затримка } \\
\text { транспортних засобів } \\
\text { при здійсненні } \\
\text { повороту ліворуч } \\
\text { (напрями 2-3 та 4-1 } \\
\text { рисунку 1), с } \\
\end{array}$} & \multicolumn{2}{|c|}{$\begin{array}{c}\text { Фактичні } \\
\text { значення } \\
\text { затримок, с }\end{array}$} \\
\hline & ранок & вечір & ранок & вечір & ранок & вечір & ранок & вечір \\
\hline Понеділок & 5,08 & 6,56 & 4,69 & 5,89 & 13,25 & 17,20 & 12,09 & 16,07 \\
\hline Вівторок & 5,59 & 4,69 & 5,01 & 4,40 & 15,69 & 10,51 & 14,78 & 10,31 \\
\hline Середа & 7,03 & 7,23 & 6,54 & 6,84 & 16,01 & 19,40 & 14,58 & 17,71 \\
\hline Четвер & 7,58 & 8,94 & 6,95 & 8,30 & 15,79 & 18,30 & 14,46 & 16,85 \\
\hline П'ятниця & 6,58 & 6,67 & 5,95 & 6,21 & 13,28 & 16,59 & 12,32 & 14,63 \\
\hline $\begin{array}{c}\text { Середнє } \\
\text { значення } \\
\text { затримки, с }\end{array}$ & 6,37 & 6,82 & 5,83 & 6,33 & 14,80 & 16,40 & 13,65 & 15,11 \\
\hline $\begin{array}{c}\text { Середня } \\
\text { похибка } \\
\text { розрахунків, } \\
\%\end{array}$ & 9,4 & 7,8 & - & - & 8,5 & 8,1 & - & - \\
\hline
\end{tabular}

Отримані результати свідчать про достатньо високу точність результатів розрахунку транспортних затримок з використанням запропонованого підходу та можливість його використання на таких об'єктах як виїзди 3 прилеглих територій. Слід також відзначити, що використання представлених в $[23,24]$ моделей дозволяє встановити середнє значення затримки транспортних засобів на обраному для дослідження об'єкті, так середнє значення транспортної затримки на виїзді 3 прилеглих прибудинкових територій по вул. Академіка Заболотного між вулицями Академіка Сахарова та Семена Палія складає: за необхідності здійснення маневру повороту праворуч 1,8 с., при здійсненні маневру повороту ліворуч $-3,1$ с.

\section{ОБГОВОРЕННЯ РЕЗУЛЬТАТІВ ДОСЛІДЖЕННЯ}

Результати оцінки точності розрахунку затримок автомобілів, що виконують маневри повороту ліворуч (пересічення) та праворуч (злиття) при виїзді з прилеглих прибудинкових територій по вул. Академіка Заболотного між вулицями Академіка Сахарова та Семена Палія в місті Одеса, 3 використанням розроблених аналітичних моделей [23, 24], свідчать про їх надійність та об'єктивність (відхилення фактичних і модельних значень транспортних затримок не перевищує 10 \%), а також можливості їх використання на етапах планування та проектування виїздів з прилеглих територій на автомагістралі, а також нерегульованих перехресть.

Але слід відзначити, що існує можливість для підвищення точності розрахунку транспортних затримок з використанням запропонованого підходу $[23,24]$. Зменшення відхилень модельних i фактичних значень транспортних затримок при виїзді з прилеглих територій можна досягти за 
рахунок врахування в моделях стохастичних характеристик параметру процесу здійснення відповідних маневрів (злиття, пересічення). За такий параметр доцільно обрати граничний часовий інтервал між автомобілями в потоці на головному напрямку, за якого будь-який автомобіль, що очікує здійснення маневру при виїзді з прилеглих територій, може здійснити маневр повороту праворуч та ліворуч, оскільки він є однією з основних складових затримки при виїзді автомобілів 3 прилеглих територій. Для отримання інформації про граничний часовий інтервал при виїзді транспортних засобів з прилеглих територій необхідне проведення натурних спостережень за діями водіїв при здійсненні маневрів повороту ліворуч і праворуч, з подальшою статистичною обробкою цих даних.

Слід розуміти, що для встановлення об'єктивної інформації про граничний часовий інтервал руху автомобілів необхідне проведення натурних спостережень за рухом транспортних засобів при виїзді 3 прилеглих територій 3 подальшою трудомісткою обробкою отриманої інформації. У літературних джерелах [25-28] представлена велика кількість підходів щодо визначення граничного часового інтервалу, але одним з перших методів оцінки критичних інтервалів є метод Раффа, який використовується в багатьох країнах [29].

В рамках даного дослідження визначено граничний часовий інтервал при виїзді транспортних засобів 3 прилеглих прибудинкових територій по вул. Академіка Заболотного між вулицями Академіка Сахарова та Семена Палія для ранкового періоду при здійсненні маневру повороту праворуч (злиття) з використанням методу Раффа, результати наведені на рисунку 4.

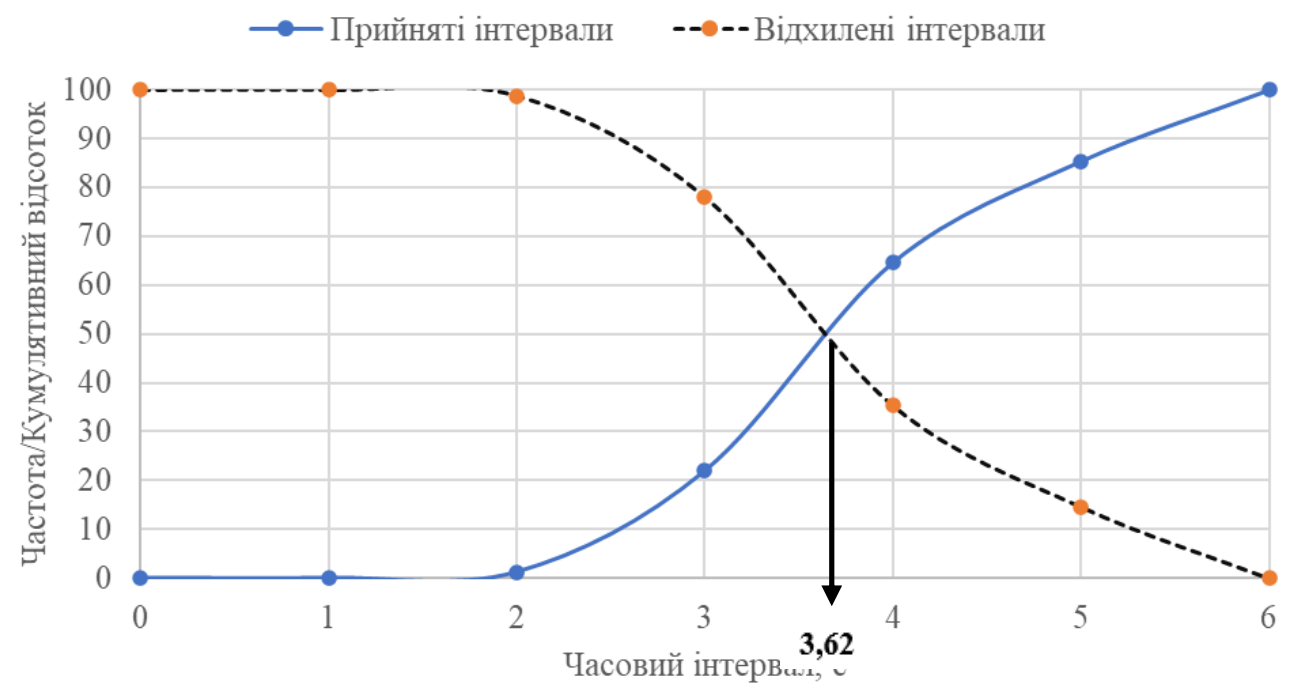

Рисунок 4 - Розрахунковий граничний інтервал за методом Раффа при виїзді транспортних засобів 3 прилеглих прибудинкових територій по вул. Академіка Заболотного між вулицями Академіка Сахарова та Семена Палія для ранкового періоду при здійсненні маневру повороту праворуч (злиття)

Значення граничного часового інтервалу при здійсненні маневру повороту праворуч на нерегульованому перехресті в [1] для різних методик його визначення (американська, датська, шведська, фінська) $є$ вищими за отримане значення граничного часового інтервалу в даному дослідженні (3,62 c). В більшому ступені, це пояснюється врахуванням в цих методиках додаткових перешкод (наприклад, звуження проїзної частини, рух вантажного транспорту), геометрію перехрестя та ін., а також особливостями організації руху транспорту при виїзді з прилеглих територій та особливостями поведінки водіїв, що характерні для таких об'єктів.

В подальшому планується уточнення результатів розрахунку граничного часового інтервалу для різних періодів доби та маневрів, що виконуються водіями при виїзді з прилеглих територій, а також виявлення закономірностей розподілу граничного часового інтервалу, за рахунок чого існує можливість підвищення точності моделювання транспортних затримок при виїзді автомобілів 3 прилеглих територій.

\section{ВИСНОВКИ}

Результати аналізу сучасних підходів щодо визначення транспортних затримок свідчать про те, що більшість 3 них застосовуються на прикладі нерегульованих перехресть 3 двостороннім контролем зупинки й з повністю контрольованою зупинкою та про необхідність розробки аналітичних моделей 
для визначення затримок автомобілів на нерегульованих перехрестях рівнозначних доріг, а також для таких об'єктів як виїзди з прилеглих територій.

За результатами натурних спостережень отримані дані, що стали основою для визначення середніх значень фактичних транспортних затримок при виїзді автомобілів з прилеглої території та встановлення закономірностей їх розподілу. Встановлено, що розподіл фактичних транспортних затримок для різних маневрів (поворот праворуч і ліворуч) відповідає логнормальному закону 3 високою імовірністю. Отримані в ході проведення натурних спостережень за трафіком дані також використані для моделювання затримок автомобілів при виїзді 3 прилеглої території за запропонованим раніше підходом.

Оцінювання точності розрахунку затримок автомобілів при виконанні маневрів поворотів праворуч (злиття) та ліворуч (пересічення) при виїзді транспортних засобів з прилеглої території за розробленим підходом проведено шляхом порівняння фактичних і модельних значень затримок транспорту. За результатами дослідження встановлено, що в середньому відхилення фактичних $\mathrm{i}$ розрахункових значень не перевищує: поворот ліворуч $-9 \%$; поворот праворуч $-10 \%$. Отримані результати підтверджують достатньо високу точність результатів моделювання транспортних затримок на виїзді з прилеглих територій з використанням розроблених аналітичних моделей.

Подальшим напрямком дослідження $€$ врахування в розроблених аналітичних моделях імовірнісного характеру зміни величини граничного часового інтервалу при здійсненні відповідних маневрів (злиття, пересічення), при виїзді з прилеглих територій, що дозволить підвищити точність моделювання затримок автомобілів на таких об'єктах.

\section{ПЕРЕЛІК ДЖЕРЕЛ ПОСИЛАННЯ}

1. Capacity and Level of Service at Finnish Unsignalized Intersections. Finnra Reports, 2004. - 214.

2. Любий Є.В. Сучасні підходи щодо визначення транспортних затримок на нерегульованих перехрестях / Є.В. Любий, О.В. Денисенко, О.М. Бєлецька // Матеріали VI Міжнародної науковотехнічної конференції «Науково-прикладні аспекти автомобільної і транспортно-дорожньої галузей», (26-27 червня 2020 року, Луцьк). - Луцьк, ЛНТУ, -2020. - С. 97-101.

3. Правила дорожнього руху [Електронний ресурс] Офіційний сайт Верховної ради України. Режим доступу : https://zakon.rada.gov.ua/laws/show/1306-2001-п.

4. Горбачов П.Ф. Щодо питання організації руху транспортних засобів при виїзді з прилеглих територій / П.Ф. Горбачов, Є.В. Любий, О.М. Бєлецька // Матеріали XII науково-практичної конференції «Сучасні технології та перспективи розвитку автомобільного транспорту», (2123.10.2019, Вінниця). - Вінниця, ВНТУ. - 2019. - С. 53-56.

5. Левашев А.Г. Проектирование регулируемых пересечений / А.Г. Левашев, А.Ю. Михайлов, И.М.Головных. - Иркутск: Изд-во ИрГТУ, 2007. - 208 с.

6. Tanner J.C. A Theoretical Analysis of Delays at an Uncontrolled Intersection / J.C. Tanner // Biometrika, vol. 49 (1/2), 1962. - P. 163-170. https://doi: 10.1093/biomet/49.1-2.163.

7. Troutbeck R.J. Average delay at an unsignalized intersection with two major streams each having a dichotomized headway distribution / R.J. Troutbeck // Transportation Science, 20(4), 1986 - P. 272-286. https://doi: 10.1287/trsc.20.4.272.

8. Heidemann D. Queue length and waiting-time distributions at priority intersections / D. Heidemann // Transportation Research Part B: Methodological 25(4), 1991. - P. 163-174. https://doi.org/10.1016/01912615(91)90001-Y.

9. Kyte M. Capacity and delay characteristics of two-way stop-controlled intersections / M. Kyte, C. Clemon, N. Mahfood, B.K. Lall, C.J. Khist // Transportation Research. Rec. 1320, 1991. - P. 160-167.

10. Horowitz A.J. Revised queueing model of delay at all-way stop-controlled intersections / A.J. Horowitz // Transportation Research. Rec., 1398, 1993. - P. 49-53.

11. Madanat S.M. Probabilistic delay model at stop-controlled intersection / S.M. Madanat, M.J. Cassidy, M.H. Wang // Journal of Transportation Engineering, 120(1), 1994. - P. 21-36. https://doi.org/10.1061/(ASCE)0733-947X(1994)120:1(21).

12. Kaysi I. Driver behavior and traffic stream interactions at unsignalized intersections / I. Kaysi, G. Alam // Journal of Transportation Engineering, 6(498), 2000. - P. 498-505. https://doi.org/ 10.1061/(ASCE)0733-947X(2000)126:6(498).

13. Akcelik R. A comparison of three delay models for sign-controlled intersections / R. Akcelik, B. Christensen, E. Chung // Third International Symposium on Highway Capacity, Copenhagen, Denmark, Volume 1. Road Directorate, Ministry of Transport, Denmark, 1998. - P. 35-56. 
14. Nielsen O.A. Stochastic User Equilibrium Traffic Assignment with Turn-delays in Intersections / O.A. Nielsen, N. Simonsen, R.D. Frederiksen // International Transactions in Operational Research, Vol. 5, No. 6, 1998. - P. 555-568. https://doi.org/10.1111/j.1475-3995.1998.tb00137.x.

15. Al-Omari B. Hybrid delay models for unsaturated two-way stop-controlled intersections / B. AlOmari, R.F. Benekohal // Journal of Transportation Engineering, 4(291), 1999. - P. 291-296. https://doi.org/10.1061/(ASCE)0733-947X(1999)125:4(291).

16. Tian Z.Z. Simulation-based study of traffic operation characteristics at all-way-stop-controlled intersections / Z.Z. Tian, M. Kyte, M. Vandehey, W. Kittelson, B. Robinson // Transportation Research Record Journal of the Transportation Research Board, 1776, 2001. - P. 75-81. https://doi.org/10.3141/177610.

17. Cvitanić D. Review, testing and validation of capacity and delay models at unsignalized intersections / D. Cvitanić, D. Breski, B. Vidjak // PROMET-Traffic\&Transportation, vol. 19(2), 2007. - P. 71-82. https://doi.org/10.7307/ptt.v19i2.937.

18. Brilon W. Delay at Unsignalized Intersections / W. Brilon // Transportation Research Record Journal of the Transportation Research Board 2071, 2008. - P. 98-108. https://doi.org/10.3141/2071-12.

19. Transportation Research Board. Highway capacity manual, Transportation Research Board of the National Academies, Washington, DC, 2010. - 1207 p.

20. Brilon W. Average Delay at Unsignalized Intersections for Periods with Variable Traffic Demand / W. Brilon // Transportation Research Record Journal of the Transportation Research Board 2483, 2015. - P. 57-65. https://doi.org/10.3141/2483-07.

21. Caliendo C. Delay Time Model at Unsignalized Intersections / C. Caliendo // Journal of Transportation Engineering, 2014. - 140(9). https://doi.org/10.1061/(ASCE)TE.1943-5436.

22. Mohammad M.A. Traffic Delay Estimation Using Artificial Neural Network (ANN) at Unsignalized Intersections / M.A. Mohammad, O.B.C. Puan // Proceedings of the 3rd International Conference on Civil, Structural and Transportation Engineering (ICCSTE'18), Niagara Falls, Canada. Paper \#106, 2018. https://doi.org/10.11159/iccste18.106.

23. Любий Є.В. Підхід щодо визначення затримок автомобілів на нерегульованих перехрестях 3 рівнозначними напрямками / Є.В. Любий, П.Ф. Горбачов, О.М. Бєлецька // Матеріали II всеукраїнської науково-технічної інтернет-конференції «Інноваційні технології розвитку машинобудування та ефективного функціонування транспортних систем», (9-11 листопада 2020 року). - Рівне, НУВГП. - 2020. - С. 94-96.

24. Горбачов П.Ф. Підхід щодо визначення затримок транспортних засобів на нерегульованих перехрестях 3 нерівнозначними напрямками / П.Ф. Горбачов, Є.В. Любий, О.М. Бєлецька // Матеріали міжнародної науково-технічної конференції «Інтелектуальні технології управління транспортними процесами», (17-18 листопада 2020 року, Харків). - Харків, ХНАДУ. - 2020. - С. 162164.

25. Євчук М.Ю. Дослідження граничних часових інтервалів на нерегульованих перехрестях / М.Ю. Свчук, О.М. Грицунь // Автомобіль і електроніка. Сучасні технології. - 2013. - Вип. 4. - С. 4547.

26. Михайлов А.Ю. Анализ математических моделей расчета интервалов следования в главных потоках для преобладающих дорожных условий российской федерации // А.Ю. Михайлов, Е.Л. Попова. - Вестник СибАДИ. - 2020. - 17(6). - С. 714-725. https://doi.org/10.26518/2071-7296-2020-176-714-725

27. Лобанов Е.М. Транспортная планировка городов / Е.М. Лобанов. - М.: 1990. - 240 с.

28. Mukti A. Defining and Analyzing Forceful Gap Behavior at Unsignalized Intersections / Mukti Advani, Neelam J. Gupta, S. Velmurugan, Erramppalli Madhu and Satish Chandra // Transportation Research Record Journal of the Transportation Research Board, Vol 2674(8), 2020. - P. 420-428. DOI: $10.1177 / 0361198120925258$.

29. Raff M.S. A Volume Warrant for Urban Stop Signs / M.S. Raff. - Eno Foundation for Highway Traffic Control, Connecticut, 1950. - 121 p.

\section{REFERENCES}

1. Capacity and Level of Service at Finnish Unsignalized Intersections (2004). Finnra Reports, 214.

2. Liubyi, Ye.V., Denysenko, O.V. \& Bieletska, O.M. (2020). Suchasni pidkhody shchodo vyznachennia transportnykh zatrymok na nerehulovanykh perekhrestiakh. Materialy VI Mizhnarodnoi 
naukovo-tekhnichnoi konferentsii «Naukovo-prykladni aspekty avtomobilnoi i transportno-dorozhnoi haluzei», 97-101.

3. Pravyla dorozhnoho rukhu (2001). Ofitsiinyi sait Verkhovnoi rady Ukrainy. https://zakon.rada.gov.ua/laws/show/1306-2001-п.

4. Horbachov, P.F., Liubyi, Ye.V. \& Bieletska, O.M. (2019). Shchodo pytannia orhanizatsii rukhu transportnykh zasobiv pry vyizdi z prylehlykh terytorii. Materialy XII naukovo-praktychnoi konferentsii «Suchasni tekhnolohii ta perspektyvy rozvytku avtomobilnoho transportu», 53-56.

5. Levashev, A.G., Mikhaylov, A.Yu. \& Golovnykh, I.M. (2007). Proektirovanie reguliruemykh peresecheniy, 208.

6. Tanner, J.C. (1962). A Theoretical Analysis of Delays at an Uncontrolled Intersection. Biometrika, vol. 49 (1/2), 163-170. https://doi: 10.1093/biomet/49.1-2.163.

7. Troutbeck, R.J. (1986). Average delay at an unsignalized intersection with two major streams each having a dichotomized headway distribution. Transportation Science, 20(4), 272-286. https://doi: 10.1287/trsc.20.4.272.

8. Heidemann, D. (1991). Queue length and waiting-time distributions at priority intersections. Transportation Research Part B: Methodological 25(4), 163-174. https://doi.org/10.1016/01912615(91)90001-Y.

9. Kyte, M., Clemon, C., Mahfood, N., Lall, B.K. \& Khis, C.J. (1991). Capacity and delay characteristics of two-way stop-controlled intersections. Transportation Research. Rec. 1320, 160-167.

10. Horowitz, A.J. (1993). Revised queueing model of delay at all-way stop-controlled intersections. Transportation Research. Rec., 1398, 49-53.

11. Madanat, S.M., Cassidy, M.J. \& Wang, M.H. (1994). Probabilistic delay model at stop-controlled intersection. Journal of Transportation Engineering, 120(1), 21-36. https://doi.org/10.1061/(ASCE) 0733947X(1994)120:1(21).

12. Kaysi, I. \& Alam, G. (2000). Driver behavior and traffic stream interactions at unsignalized intersections. Journal of Transportation Engineering, 6(498), 498-505. https://doi.org/ 10.1061/(ASCE)0733947X(2000)126:6(498).

13. Akcelik, R., Christensen, B. \& Chung, E. (1998). A comparison of three delay models for signcontrolled intersections. Third International Symposium on Highway Capacity, Copenhagen, Denmark, Volume 1. Road Directorate, Ministry of Transport, Denmark, 35-56.

14. Nielsen, O.A., Simonsen, N. \& Frederiksen, R.D. (1998). Stochastic User Equilibrium Traffic Assignment with Turn-delays in Intersections. International Transactions in Operational Research, Vol. 5, No. 6,. 555-568. https://doi.org/10.1111/j.1475-3995.1998.tb00137.x.

15. Al-Omari, B. \& Benekohal, R.F. (1999). Hybrid delay models for unsaturated two-way stopcontrolled intersections. Journal of Transportation Engineering, 4(291), 291-296. https://doi.org/10.1061/(ASCE)0733-947X(1999)125:4(291).

16. Tian, Z.Z., Kyte, M., Vandehey, M., Kittelson, W. \& Robinson, B. (2001). Simulation-based study of traffic operation characteristics at all-way-stop-controlled intersections. Transportation Research Record Journal of the Transportation Research Board, 1776, 75-81. https://doi.org/10.3141/1776-10.

17. Cvitanić, D., Breski, D. \& Vidjak, B. (2007). Review, testing and validation of capacity and delay models at unsignalized intersections. PROMET-Traffic\&Transportation, vol. 19(2), 71-82. https://doi.org/10.7307/ptt.v19i2.937.

18. Brilon, W. (2008). Delay at Unsignalized Intersections. Transportation Research Record Journal of the Transportation Research Board 2071, 98-108. https://doi.org/10.3141/2071-12.

19. Transportation Research Board (2010). Highway capacity manual, Transportation Research Board of the National Academies, Washington, DC, 1207.

20. Brilon, W. (2015). Average Delay at Unsignalized Intersections for Periods with Variable Traffic Demand. Transportation Research Record Journal of the Transportation Research Board 2483, 57-65. https://doi.org/10.3141/2483-07.

21. Caliendo, C. (2014). Delay Time Model at Unsignalized Intersections. Journal of Transportation Engineering, 140(9). https://doi.org/10.1061/(ASCE)TE.1943-5436.

22. Mohammad, M.A. \& Puan, O.B.C. (2018). Traffic Delay Estimation Using Artificial Neural Network (ANN) at Unsignalized Intersections. Proceedings of the 3rd International Conference on Civil, Structural and Transportation Engineering (ICCSTE'18), Niagara Falls, Canada. Paper \#106. https://doi.org/10.11159/iccste18.106. 
23. Liubyi, Ye.V., Horbachov, P.F. \& Bieletska, O.M. (2020). Pidkhid shchodo vyznachennia zatrymok avtomobiliv na nerehulovanykh perekhrestiakh z rivnoznachnymy napriamkamy. Materialy II vseukrainskoi naukovo-tekhnichnoi internet-konferentsii «Innovatsiini tekhnolohii rozvytku mashynobuduvannia ta efektyvnoho funktsionuvannia transportnykh system, 94-96.

24. Horbachov, P.F., Liubyi, Ye.V. \& Bieletska, O.M. (2020). Pidkhid shchodo vyznachennia zatrymok transportnykh zasobiv na nerehulovanykh perekhrestiakh $\mathrm{z}$ nerivnoznachnymy. Materialy mizhnarodnoi naukovo-tekhnichnoi konferentsii «Intelektualni tekhnolohii upravlinnia transportnymy protsesamy», 162-164.

25. Yevchuk, M.Iu. \& Hrytsun, O.M. (2013). Doslidzhennia hranychnykh chasovykh intervaliv na nerehulovanykh perekhrestiakh. Avtomobil i elektronika. Suchasni tekhnolohii., 45-47.

26. Mikhaylov, A.Yu. \& Popova, Ye.L. (2020). Analiz matematicheskikh modeley rascheta intervalov sledovaniya $\mathrm{v}$ glavnykh potokakh dlya preobladayushchikh dorozhnykh usloviy rossiyskoy federatsii. Vestnik SibADI, 714-725. https://doi.org/10.26518/2071-7296-2020-17-6-714-725

27. Lobanov, Ye.M. (1990). Transportnaya planirovka gorodov, 240.

28. Mukti Advani, Neelam J. Gupta, S. Velmurugan, Erramppalli Madhu \& Satish Chandra (2020). Defining and Analyzing Forceful Gap Behavior at Unsignalized Intersections. Transportation Research Record Journal of the Transportation Research Board, 420-428. DOI: 10.1177/0361198120925258.

29. Raff, M.S. (1950). A Volume Warrant for Urban Stop Signs. Eno Foundation for Highway Traffic Control, 121.

\section{Ye. Liubyi, O. Bieletska Experimental research of traffic delays at the adjacent territory exit}

The presented scientific work is devoted to the study of problem to determine traffic delays at the adjacent territory exit on city highways. Currently there are already a large number of different approaches to determine delays at unsignalized intersections have been developed, but they don't fully take into account the aspects of traffic organization and drivers' behavior at the adjacent territory exit.

The results of field observations of traffic at the adjacent territory exit are the basis for the delays evaluation, which are determined by the proposed approach. The developed approach to determine traffic delays is based on the queuing theory and taken into account the priority of traffic in competing directions. It was established that the deviation of factual transport delays and delays obtained by the proposed approach for maneuvers of turns to the right (merging) and left (crossing) does not exceed $10 \%$, which indicates the possibility of its use at such objects as the adjacent territory exit. Based on the empirical data obtained it was determined the factual delays distribution of vehicles at the adjacent territory exit which for all considered cases corresponds to the lognormal law with a fairly high probability.

To reduce the deviations of model and factual transport delays at the adjacent territory exit it is necessary to take into account the stochastic characteristics of parameters the process of making maneuvers of turns to the right and left in the model. Such a parameter is critical interval between vehicles in the main direction (road), at which any vehicle waiting for a maneuver at the adjacent territory exit, will be able to turn right (merging) or left (crossing), which can be determined by statistical processing of the results of field observations.

Key words: traffic flow, delay, critical gap, adjacent territory exit, field observations

ЛЮБИЙ Свген Володимирович, кандидат технічних наук, доцент кафедри транспортних систем i логістики, Харківський національний автомобільно-дорожній університет e-mail: lion_khadi@ukr.net https://orcid.org/0000-0003-0681-0920

БСЛЕЦЬКА Ольга Михайлівна, здобувач (аспірант) кафедри транспортних систем і логістики, Харківський національний автомобільно-дорожній університет e-mail: Olya.Krasotova@gmail.com https://orcid.org/0000-0002-6256-8705

Yevhen LIUBYI, PhD, Associate Professor of Transport Systems and Logistics Department, Kharkiv National Automobile and Highway University e-mail: lion_khadi@ukr.net https://orcid.org/0000-0003$\underline{0681-0920}$

Olha BIELETSKA, Postgraduate of Transport Systems and Logistics Department, Kharkiv National Automobile and Highway University e-mail: Olya.Krasotova@gmail.com https://orcid.org/0000-0002-6256$\underline{8705}$

DOI 10.36910/automash.v1i16.513 